\title{
Kişilik Bozukluklarıyla Çalışmada Zorluk Ölçeği (KB-ÇZÖ)
}

$\mathrm{Bu}$ ölçek kişilik bozukluğu hastaları ile çalışırken genel olarak zorlandığınız durumları ve zorlanma düzeyinizi değerlendirmeyi amaçlamaktadır. Tamamen kişisel deneyim- lerinize dayanarak, aşağıda zorluk alanlarından oluşan her maddeyi Hiç: (0), Az: (1), Orta: (2), Çok: (3) puanları arasından size uyan seçeneğe göre işaretleyiniz.

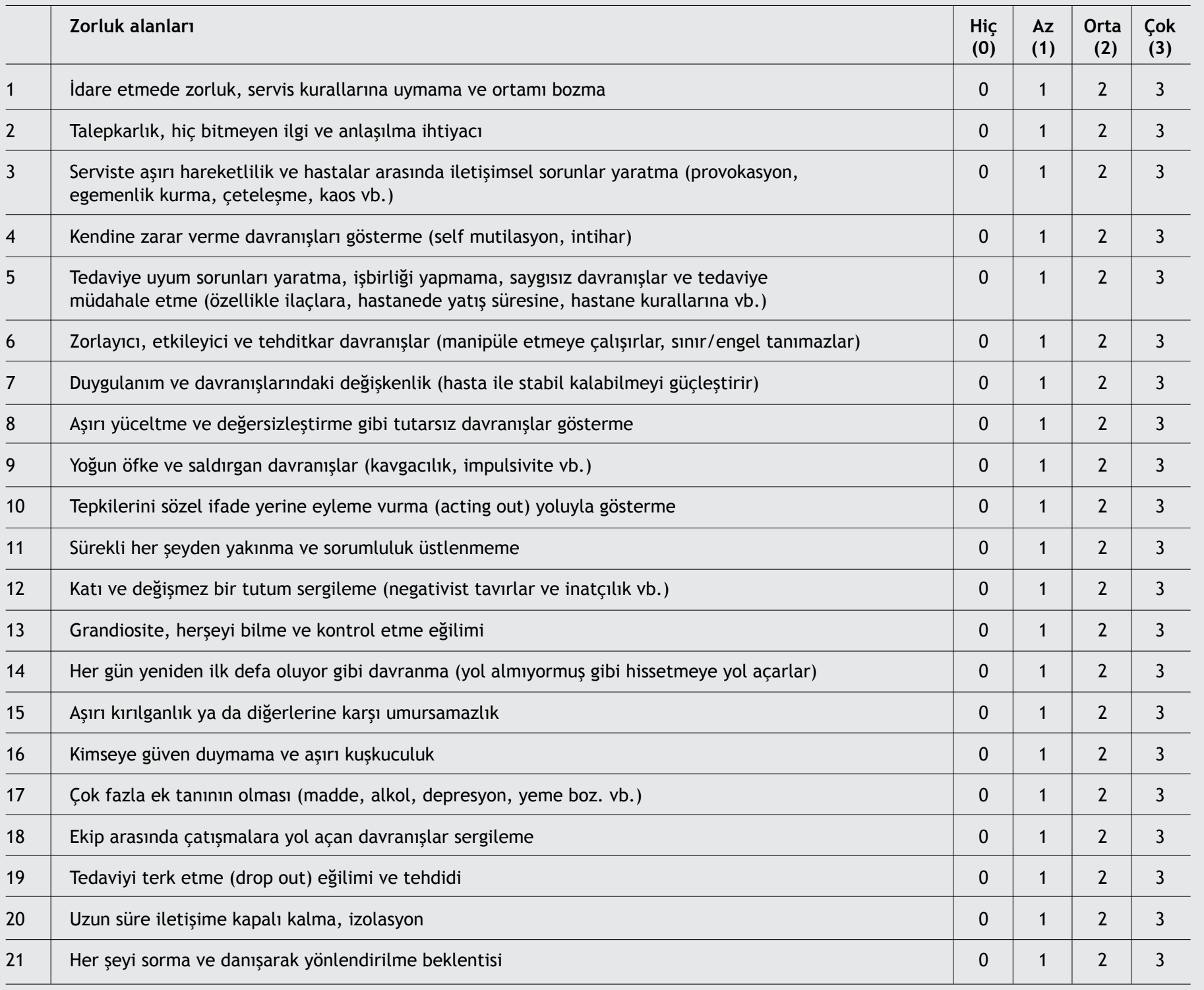

Ölçek 2013 yılında Eren ${ }^{[1]}$ tarafından geliştirilmiş ve geçerlik-güvenirlik çalışması yapılmıştır. 21 maddeden oluşan ölçekte dörtlü likert tipi değerlendirme sistemi kullanılmıştır. Derecelendirme maddeleri: "Hiç (0) ”, “Az (1) “, Orta (2)" ve "Çok (3)" olarak belirlenmiştir. Aritmetik ortalamanın değerlendirme aralığı için $(4-1=3)$ hesaplanan aralık katsayıs1na göre $(3 / 4=.75)$ seçenek aralıkları düzenlenmiştir. (0-.74) arasındaki ortalamalar "hiç", (.75-1.4) arasındaki ortalamalar "az", (1.5-2.24) arasindaki ortalamalar "orta", (2.25-3.0) arasındaki ortalamalar "çok" olarak derecelendirilmiştir.

Geçerlik-faktör yapısına ilişkin açımlayıcı faktör analiz sonucunda KMO değerinin .946 olduğu belirlenmiştir. Ayrıca Bartlett testi sonuçları incelendiğinde, $\mathrm{X}^{2}$ (ki-kare) değerinin anlamlı olduğu görülmüştür $\left(X^{2}(210)=4708.032 ; \mathrm{p}<.001\right)$. 
Yapılan güvenirlik analizlerinde test-tekrar test katsayısı .7020; test toplamının cronbach alfa değeri .9522; Spearman Brown değeri .880 ve Gutman değeri .867 olarak bulunmuştur. Ayrıca testin güvenirliği için; ölçmenin standart hata değeri 2.44'dür.

Ölçeğin aritmetik ortalaması 28.49; medyanı ise 26.90'dur. Testin toplam puanı madde puanlarının toplanmasiyla elde edilmektedir. Testten alınabilecek maksimum puan 63'tür. Testten 12 ve altında puan alanlar düşük zorluk yaşarlarken, 45 puan ve üstü alanlar yüksek düzeyde sorun yaşamaktadır.
Ölçek kişilik bozukluğu hastalarıyla çalışan ruh sağlığı çalışanlarının bu hastalarla çalı̧̧maya ilişkin zorlanma derecelerini ve zorluk alanlarını değerlendirmeyi amaçlamaktadır. Ölçek hem toplam puan hem de maddeler üzerinden kullanilabilir.

\section{Kaynak}

1. Eren N. Kişilik bozukluklarıyla çalışmada zorluk ve kişilik bozukluğu hastalarına karşı tutumlar ölçeklerinin psikometrik özellikleri. Nöropsikiyatri Arşivi. 2013 (doi: 10.4274/npa.y7056.).

\section{Düzeltme / Erratum}

Psikiyatri Hemşireliği Dergisi Cilt 4, Sayı 1, s. 55

Psikiyatri Hemşireliği Dergisi, Cilt 4, 1. sayısında, sayfa 55'de “Ölçek Tanıtımı” başlığı sehven hatalı yazılmıştır. Doğrusu

"Kişilik bozukluğu hastalarına karşı tutumlar ölçeği (KBH-TÖ)" olacaktır. Düzeltiriz. 